Jurnal Pemberdayaan: Publikasi Hasil Pengabdian kepada Masyarakat

Vol. 4, No. 3, Desember 2020, Hal. 275-278

ISSN: 2580-2569; e-ISSN: 2656-0542

DOI: https://doi.org/10.12928/jp.v4i3.1995

\title{
Peran Serta Kader dalam Pemenuhan Kelengkapan dan Ketepatan Pencatatan Data Posyandu Anyelir 1 Dusun Wonocatur, Banguntapan, Bantul
}

\author{
Nur Syarianingsih Syam, Nungky Angginia Ningrum, Denda Sabrina Emily, Nurul Liana \\ Herianti, Sofia Fitria Dewi, Rida Kurnia Hijriani
}
Program Studi Kesehatan Masyarakat, Fakultas Kesehatan Masyarakat, Universitas Ahmad Dahlan, Kampus 3, Yogyakarta, Indonesia
Email: nur.syam@ikm.uad.ac.id

\begin{abstract}
ABSTRAK
Posyandu merupakan salah satu bentuk upaya kesehatan bersumber daya masyarakat yang dikelola dan diselenggarakan dari, oleh, untuk dan bersama masyarakat dalam penyelenggaraan pembangunan kesehatan, guna memberdayakan masyarakat dan memberikan kemudahan kepada masyarakat dalam memperoleh pelayanan kesehatan dasar, utamanya untuk mepercepat penurunan angka kematian ibu dan bayi. Pengabdian ini bertujuan meningkatkan pengetahuan kader terhadap pentingnya kelengkapan dan ketepatan pencatatan data kegiatan posyandu. Metode yang digunakan pada pengabdian ini adalah ceramah, simulasi dan tanya jawab. Sasaran pengabdian ini adalah kader Posyandu Anyelir 1 Dusun Wonocatur. Hasil diketahui kendala dalam melengkapi laporan data posyandu adalah pengetahuan dan usia kader. Dampak dari pengabdian ini adalah terjadi peningkatan pengetahuan kader terkait kelengkapan dan ketepatan pencatatan, pendokumentasian dan pelaporan data kegiatan posyandu.
\end{abstract}

Kata kunci: Pengetahuan, Posyandu, Kader

\begin{abstract}
Posyandu is a one of community-based health sevices managed and organized from, by, for and with the community in the implementation of health development, in order to empower the community and provide facilities to the public in obtaining basic health services, primarily to accelerate the reduction in maternal and infant mortality rates. . This service aims to increase cadre's knowledge on the importance of completeness and accuracy in recording posyandu activity data. The method used in this service is lecture, simulation and question and answer. The target of this service is cadre Posyandu Anyelir 1 Wonocatur Village. The results are known to be obstacles in completing the posyandu data report is the knowledge and age of members. The impact of this service is an increase in member has knowledge related to the completeness and accuracy of recording, documenting and reporting data on posyandu activities
\end{abstract}

Keywords: Knowledge, Posyandu, Member

\section{PENDAHULUAN}

Pemeliharaan dan perawatan kesejahteraan ibu dan anak sejak usia dini merupakan suatu strategi dalam upaya pemenuhan pelayanan dasar yang dapat dilakukan di Posyandu (Nurhidayah, dkk. 2019). Posyandu merupakan salah satu bentuk upaya kesehatan bersumber daya masyarakat yang dikelolah dan diselenggarakan untuk masyarakat dalam penyelenggaraan pembangunan kesehatan, memberdayakan masyarakat dan memberikan kemudahan kepada masyarakat dalam memperoleh pelayanan kesehatan dasar untuk mempercepat penurunan angka kematian ibu dan bayi (Kemenkes, 2011). Posyandu adalah ujung tombak pelayanan kesehatan yang memiliki tujuan untuk mempercepat upaya penurunan 
Angka Kematian Bayi (Infant Mortality Rate), Angka Kelahiran Bayi (Birth Rate). Ada berbagai kegiatan yang dilaksanakan di posyandu yaitu kegiatan pemantauan tumbuh kembang balita, pelayanan kesehatan ibu dan anak termasuk pemberian imunisasi guna pencegahan penyakit, penanggulangan kejadian diare, pelayanan $\mathrm{KB}$, penyuluhan dan konseling/rujukan konseling apabila dibutuhkan (Profita, 2018).

Tujuan didirikannya Posyandu adalah untuk menurunkan angka kematian bayi dan anak balita, angka kelahiran agar terwujud keluarga kecil bahagia dan sejahtera, Pos pelayanan terpadu (Posyandu) ini merupakan wadah titik temu antara pelayanan professional dari petugas kesehatan dan peran serta masyarakat dalam menanggulangi masalah kesehatan masyarakat, terutama dalam upaya penurunan angka kematian bayi dan angka kelahiran. Peranan kader sangat penting karena kader bertanggung jawab dalam pelaksanaan program posyandu. Bila kader tidak aktif maka pelaksanaan posyandu juga akan menjadi tidak lancar dan akibatnya status gizi balita tidak dapat dideteksi secara dini dengan jelas. Kader diharapkan berperan aktif dan mampu menjadi pendorong, motivator dan penyuluh masyarakat (Onthonie, dkk. 2015).

Dalam proses kegiatan Posyandu salah satu tugas dari kader Posyandu adalah mencatat seluruh hasil kegiatan Posyandu dengan menggunakan format baku sesuai dengan program kesehatan. Keseluruhan format tersebut dikumpulkan dan disebut sebagai Sistem Informasi Posyandu (Kemenkes, 2012). Keberlangsungan kegiatan pencatatan ini sangat bergantung pada partisipasi aktif dari kader Posyandu (Devi, dkk. 2014). Partisipasi aktif kader ditandai dengan tingginya kelengkapan dan ketepatan pengisian data kegiatan posyandu. Menurut teori PRISM (Performance of Routine Information System Management), faktor yang mempengaruhi kelengkapan pengumpulan data kesehatan, salah satunya adalah faktor perilaku (pengetahuan, kebutuhan data, kompetensi, motivasi, ketrampilan). Faktor perilaku adalah faktor yang berpengaruh langsung pada kelengkapan pengumpulan data kesehatan (Ariyanti, dkk. 2016)

Data Profil Kabupaten Bantul Tahun 2018, menunjukkan jumlah Posyandu yang tersebar di Kabupaten Bantul mengalami peningkatan dari tahun 2016 terdapat 1137 dan tahun 2017 terdapat 1141 posyandu. Jumlah balita yang ada di Kabupaten Bantul mengalami penurunan dari tahun 2016 terdapat 58.851 balita, tahun 2017 menjadi 58.255 balita. Puskesmas Banguntapan 3 adalah Puskesmas yang terdapat di wilayah Kabupaten Bantul. Puskesmas ini menangungi 33 posyandu (Pemkab Bantul, 2018).

Posyandu Anyelir 1 merupakan salah satu posyandu binaan Puskesmas Banguntapan 3 yang berdiri sejak tahun 1987 di wilayah Dusun Wonocatur. Posyandu Anyelir 1 melakukan kegiatan setiap bulan pada tanggal 11. Dalam menjalankan memberikan pelayanan Posyandu, diketahui terdapat kendala dalam proses pencatatan dan pendokumentasian kegiatan. Berdasarkan hasil observasi yang dilakukan pada bulan Februari, 2020 diketahui kendala ketepatan dan kelengkapan pencatatan oleh kader dikarenakan pengetahuan, usia dan jumlah kader yang terbatas.

Peningkatan pengetahuan kader terkait kelengkapan dan ketepatan dalam pencatatan menjadi dasar tujuan diadakannya pengabdian ini. Adapun mitra pada pengabdian ini adalah Posyandu Anyelir 1 Dusun Wonocatur.

\section{METODE}

Metode yang digunakan pada pengabdian ini adalah dengan penyuluhan atau ceramah dan simulasi. Metode penyuluhan adalah proses penyebarluasan informasi tentang ilmu pengetahuan, teknologi, maupun seni. Sehingga media penyuluhan dapat diartikan sebagai sarana atau upaya untuk menampilkan pesan informasi yang ingin disampaikan oleh komunikator sehingga sasaran dapat meningkat pengetahuannya yang akhirnya dapat berubah perilakunya ke arah positif terhadapa kesehatan (Susilowati, 2016). Metode simulasi adalah metode melakukan kegiatan tiruan terhadap sesuatu yang nyata, terhadap keadaan 
sekelilingnya atau proses. Kegiatan penyuluhan ini terbagi menjadi dua sesi (Sudjana \& Rivai, 2005). Sesi pertama adalah sosialisai format data SIP dan sesi kedua adalah simulasi pengisian data SIP. Selanjutnya, Tabel 1 menunjukkan rincian metode pelaksanaan penyuluhan pada kegiatan pengabdian

Tabel 1. Metode Pelaksanaan Penyuluhan Ketepatan dan Kelengkapan Data Posyandu Anyelir 1

\begin{tabular}{|c|c|c|c|c|}
\hline No & Metode & Nama Kegiatan & $\begin{array}{l}\text { Tanggal } \\
\text { pelaksanaan dan } \\
\text { Alokasi Waktu }\end{array}$ & Sasaran \\
\hline 1 & $\begin{array}{l}\text { Penyuluhan } \\
\text { Urgensi } \\
\text { Kader dan } \\
\text { Format data } \\
\text { Posyandu }\end{array}$ & $\begin{array}{l}\text { a. Penyuluhan Urgensi Kader } \\
\text { Posyandu } \\
\text { b. Penyuluhan Format data } \\
\text { Posyandu } \\
\text { c. Tanya jawab }\end{array}$ & $\begin{array}{l}11 \text { Februari } 2020 \\
100 \text { menit }\end{array}$ & $\begin{array}{l}\text { Kader } \\
\text { Posyandu }\end{array}$ \\
\hline 2 & Simulasi & Pengisian Form data Posyandu & $\begin{array}{l}12 \text { Februari } 2020 \\
100 \text { menit }\end{array}$ & $\begin{array}{l}\text { Kader } \\
\text { Posyandu }\end{array}$ \\
\hline
\end{tabular}

\section{HASIL, PEMBAHASAN, DAN DAMPAK}

Berdasarkan Tabel 1, diketahui di hari pertama kader Posyandu Anyelir 1 diberikan penyuluhan terkait peran serta kader dalam memberikan data yang berkualitas. Data yang berkualitas bisa dihasilkan jika pencatatan dan pelaporan dilakukan secara tepat dan lengkap. Di hari kedua dilakukan praktik pengisian form data posyandu untuk mengetahui tingkat pemahaman kader terhadap materi yang telah disampaikan di hari sebelumnya.

Hasil dari pengabdian ini di hari pertama diketahui kendala-kendala yang dihadapi kader dalam melengkapi form data kegiatan posyandu. Kendala yang dihadapi kader adalah kuranngnya pengetahuan terkait cara pengisian form data SIP. Setelah diberikan edukasi pengetahuan kader terkait cara pengisian mengalami peningkatan. Ada enam form yang dikenalkan kepada kader yaitu Form 1: Catatan ibu hamil, kelahiran, kematian bayi, dan kematian ibu (hamil, melahirkan, nifas). Form 2: Register Bayi dan Balita dalam wilayah kerja posyandu selama 1 tahun. Form 3: Register WUS-PUS dalam wialayah kerja Posyandu selama 1 tahun. Form 4: Register ibu hamil dalam wilayah kerja Posyandu selama 1 tahun. Form 5: Data hasil kegiatan posyandu. Form 6: Data Posyandu (Kemenkes, 2012).

Kualitas data yang dicatatkan dan dilaporkan dipengaruhi oleh pengetahuan dan motivasi kader (Devi, 2014). Salah satu starategi untuk mengubah perilaku adalah dengan pemberian informasi guna meningkatkan pengetahuan sehingga timbul kesadaran yang pada akhirnya individu akan berperilaku sesuai dengan pengetahuannya tersebut (Notoatmodjo, 2012). Salah satu cara pemberian informasi adalah dengan memberikan pelatihan yang dilakukan oleh petugas kesehatan. Peningkatan pengetahuan kader setelah pelatihan bisa terjadi bila materi yang disampaikan mudah dimengerti oleh kader (Lubis \& Syahri, 2015). Faktor lain yang mempengaruhi kualitas kelengkapan laporan adalah usia kader. Seorang kader akan tetap menjaid kader sampai seseorang tesebut memutuskan untuk tidak lagi menjadi kader, karena tidak ada peraturan yang menyebutkan mengenai batasan usia menjadi kader, sehingga banyak kader yang meskipun sudah berusia lanjut tetap menjadi kader (Nurayu, 2013). 


\section{SIMPULAN}

Pelaksanaan pengabdian ini terdiri dari dua metode yakni penyuluhan dan simulasi. Diketahui bahwa faktor penyebab tidak lengkap pendokumentasian buku Posyandu yakni umur dan tingkat pengetahuan. Hasil dari pengabdian ini adalah terjadi peningkatan pengetahuan kader terkait data SIP.

\section{UCAPAN TERIMAKASIH}

Tim pelaksana kegiatan pengabdian kepada masyarakat mengucapkan banyak terimakasih kepada Fakultas Kesehatan Masyarakat Universitas Ahmad dahlan dan para Kader Posyandu Anyelir 1 Dusun Wonocatur.

\section{DAFTAR PUSTAKA}

Ariyanti, C., Dharmawan, Y., \& Mawarni, A. (2016). Hubungan Faktor Perilaku Dengan Kelengkapan Pengisian Data Kms Dalam Buku Kia Oleh Kader Posyandu Di Wilayah Kerja Puskesmas Sidorejo Lor Salatiga Tahun 2016. Jurnal Kesehatan Masyarakat (eJournal), 4(4), 177-185.

Devi, W.S. (2014). Faktor Yang Berhubungan Dengan Kelengkapan Pencatatan Sistem Informasi Posyandu Di Kecamatan Panti Kabuaten Jember. Jember: Universitas Jember. Kemenkes dan Pokjanal Posyandu Pusat. (2012). Kurikulum dan Modul Pelatihan Kader Posyandu. Jakarta: Kementerian Kesehatan Republik Indonesia.

Kemenkes RI. (2011). Pedoman Pengelolaan Posyandu. Jakarta: Kemeterian Kesehatan RI.

Lubis, Z., \& Syahri, I.M. (2015). Pengetahuan dan Tindakan Kader Posyandu Dalam Pemantauan Pertumbuhan Anak Balita. Jurnal Kesehatan Masyarakat (Kemas), 11(1), 65-73.

Notoatmodjo, S. (2012). Promosi Kesehatan dan Perilaku Kesehatan. Jakarta: Rineke Cipta.

Nurayu, A.W. (2013). Hubungan Tingkat Pengetahuan, Pendidikan, Usia dan Lama Menjadi Kader Posyandu dengan Kualitas Laporan Bulanan Data Kegiatan Posyandu. Surakarta: Universitas Muhammadiyah Surakarta.

Nurhidayah, I., Hidayati, N.O., \& Nuraeni, A. (2019). Revitalisasi Posyandu melalui Pemberdayaan Kader. $M K K, 2(2), 145-157$.

Onthonie, H., Ismanto, A., \& Onibala, F. (2015). Hubungan Peran Serta Kader Posyandu Dengan Status Gizi Balita Di Wilayah Kerja Puskesmas Manganitu Kabupaten Kepulauan Sangihe. Jurnal Keperawatan UNSRAT, 3(2),106-264.

Pemkab Bantul. (2018). KABUPATEN BANTUL TAHUN 2018. Bantul: Pemkab Bantul.

Profita, A.C. (2018). Beberapa Faktor Yang Berhubungan Dengan Keaktifan Kader Posyandu Di Desa Pengadegan Kabupaten Banyumas. Jurnal Administrasi Kesehatan Indonesia, 6(2), 68.

Sudjana, N., \& Rivai, A. (2005). Media Pengajaran. Bandung: Sinar Baru Algendindo. Susilowati, D. (2016). Promosi Kesehatan. Jakarta: BPPSDMK Kemeknkes RI. 